The Quarterly Journal of Austrian Economics

Volume 24 | No.3 | 450-466 | Fall 2021 WWW.QJAE.ORG

\title{
The Colonization Cost Theory of AnARChic EMERgence
}

\author{
Vladimir MaltseV*
}

JEL Classification: N41, N42, N43, Z12

AвSTRACT: The paper describes the colonization cost theory of anarchic emergence. The theory states that when the state incurs high costs of directly colonizing land, it may be beneficial for it to allow anarchy to emerge and settle distant frontiers. Once enough land is settled by the anarchic community, the state can then use one of the two following strategies: 1) appropriate this land cheaply by a coercive takeover; 2) wait for the anarchic communities to assimilate into the state, given the state's low time preference. The theory is empirically supported through two cases of Russian religious sects. The first case describes the Old Believers sect that was forced to escape state persecution to the Altai mountains in the 1740s. In 1791 these Old Believers were re-integrated into the Russian state after a series of violent military clashes. The second case describes the Doukhobors sect. This sect was incentivized to immigrate to Canada for the purpose of settling the distant prairies in Saskatchewan. The Canadian government expected the Doukhobors to assimilate after a few years of living under anarchy, but after seeing this approach fail, resorted to a coercive strategy and appropriated the colonized land.

Since its inception, the Austrian school of economics stressed the
importance of spontaneous order, which originates in human

\footnotetext{
*Vladimir Maltsev (vmaltsev92@gmail.com) is a senior lecturer at the Financial University under the Government of the Russian Federation.

I want to thank the journal editor and an anonymous referee for providing valuable feedback and comments. I further thank Natasha Purser for helping me with language editing. 
action. This emphasis eventually led to the intertwining of the Austrian research framework and the study of anarchy. ${ }^{1}$ Through the logic of human action as outlined in the works of Carl Menger, Ludwig von Mises, and F. A. Hayek, many prominent Austrian scholars attempted to explain how stateless societies can privately supply law, security, and a plethora of other public goods (see, for instance, Hoppe 1998-99; and Rothbard 2006). Today, the Austrian analysis of anarchy continues and is increasingly empirical, focusing on mechanisms which promote and enforce cooperation (Leeson 2007, 2013; Powell, Ford, and Nowrasteh 2008; and Stringham 2015). This synthesis of the Austrian school approach and the study of anarchy is classified (Boettke 2011) as a "progressive research paradigm" in economic sciences.

Despite the immense progress in the study of anarchy, the question of how to get there receives little attention. The answers given by the scholarship seemingly have not evolved beyond a handful of basic explanations. However, as the Austrian school has constantly stressed the need to examine institutions and their dynamic nature, the lack of progress in such an important field of inquiry as emergence cannot be ignored. In other words, how can a phenomenon be fully understood if the various ways in which it originated are ignored?

This article claims that under particular economic constraints, anarchy can emerge as a result of deliberate effort by the state- a dynamic that has been completely ignored in contemporary studies. This insight might also result in a rather paradoxical situation where spontaneous orders may not exist as a result of deliberate human design but their emergence might very well be fostered deliberately.

When is it beneficial for a state to cause statelessness to emerge? The colonization cost theory presented in this article answers this

\footnotetext{
${ }^{1}$ In this paper, I define anarchy as "the absence of government," and not necessarily as a community that employs private defense agencies for its functioning (it may, in fact turn to other means of securing peace, as mentioned by Long $(2007,154-60)$. In turn, I borrow from Leeson (2014) the definition of government as a "monopoly governing agency that compels persons to abide by the social rules it creates, but which all those persons haven't explicitly consented to be governed by." As such, the matter of explicit consent and the ability to exit a governance arrangement is key for distinguishing anarchy from the state in this framework. Both these definitions come with a set of inherent problems, but they are adequate for the purposes of this article.
} 
question. This theory holds that when the costs of directly colonizing new land are high, a state can incentivize the creation of anarchic communities in unsettled stateless regions. Then, once a sufficient amount of territory has been developed by the anarchic colonizers, the state will either subjugate the stateless territories or wait for the colonizers to assimilate into it, receiving new lands at a significantly lower cost as compared to direct expansion.

The research tackling anarchic emergence (see, for instance, Ellickson 1986; Tannehill and Tannehill 1993; Anderson and Hill 2004; Rothbard 2006; Leeson 2007, 2013; Powell, Ford, and Nowrasteh 2008; Scott 2009; Stringham and Miles 2012; Chartier 2013; and Friedman 2014) forms the theoretical foundation of this paper. This study finds empirical support for the colonization cost theory in two examples from Russian history that deal with oppressed religious sects. One such sect, the Old Believers, was forced by the government to flee to Siberia, and after developing a sufficient amount of land in the region, they were reintegrated into the state (see, for instance, Zenkovsky 1957; Michels 1999; and Maltsev 2019). Another example is the anarchic sect of Doukhobors, who fled to Canada motivated by its federal land grants, which were meant to incentivize the colonization of the prairies. The Canadian government expected the Doukhobors to assimilate, but eventually expropriated the sect's developed lands (Bulgakov 1994; Somin 2004; Androsoff 2011; and Makarova 2013).

The article is structured as follows. First, the literature on anarchic emergence is reviewed. Then, the colonization cost theory of anarchic emergence is presented and empirical support for it is presented. Section five concludes and offers suggestions for new potential areas of my theory's application.

\section{LITERATURE REVIEW}

The views on anarchic emergence have varied among scholars but can usually be condensed to the following theories. Rothbard (2006) and Chartier (2013), for instance, stress the importance of education or ideological conversion in the emergence of anarchy. Rothbard $(2006,373)$ stresses that this may occur through "the persuasion and conversion of large numbers of people to the cause." Chartier 
$(2013,321)$ notes the importance of actively practicing political and cultural anarchism to speed up the emergence of anarchy in general.

Another understanding of anarchic emergence can be classified as "state failure," where states are unwilling or unable to adequately provide governance or public goods, due to their corruption, overall incompetence, or simple costliness. For David Friedman (2014, 156) the efficiency that private institutions exhibit over state ones is at the core of the path toward anarchy. The development of these alternatives constructs the "skeleton of anarcho-capitalism," from which anarchy then emerges. Morris and Linda Tannehill (1993, 151-52) present similar views, claiming that anarchy can emerge after the collapse of the state due to its disastrous economic policies. Stringham $(2015,233)$ further argues that if individuals can recognize the "unreliability of politicians and the inefficacy of the laws they impose," they will not "so willingly support rules and regulations, and that can aid in replacing government rules and regulations with private ones." The state inefficiencies can also create what Ellickson (1986) and Leeson (2013) call "pockets" of anarchy within states.

A different explanation for anarchic emergence comes from the "power vacuum" theories. Works on anarchy in Somalia by Peter T. Leeson (2007) and Benjamin Powell, Ryan Ford, and Alex Nowrasteh (2008) show that anarchy can emerge as the population of a country disposes of a predatory state without actively attempting to establish a new one. Moreover, conflicts between states themselves can leave behind unoccupied swathes of land devoid of political rule (Maltsev 2019). Anarchy can take hold in such power vacuums.

Finally, the research of Terry L. Anderson and Peter J. Hill (2004) on the Wild West and James C. Scott (2009) on Zomia shows that anarchy emerges when individuals leave the states that they inhabit, lured by the chance to attain profits outside of the state's sphere of influence or to simply flee its tyranny.

Murphy $(2010,29)$ urges us to be cautious however, stating that a path to anarchy will depend on the particular historical conditions in a given society. While one society may transition to anarchy via a "violent overthrow of unjust regimes," the others may enjoy a "gradual and orderly erosion of the state."

Since these scholarly efforts, almost no attempts have been made to offer new explanations as to how anarchy can emerge, and in no 
way did the reviewed literature consider a situation where the state purposefully fosters anarchy. By considering such a possibility, this paper offers a new explanation that ameliorates the stagnancy in the field of anarchic emergence studies.

\section{THE COLONIZATION COST THEORY OF ANARCHIC EMERGENCE}

The idea that individuals flee the state's territory and colonize uninhabited lands outside its sphere of influence is not novel by itself. Such processes are well described in the literature on the Wild West (Anderson and Hill 2004; Stringham 2015, 113-33), which describes how individuals moved out of the reach of United States law to the western frontier of North America, lured by the prospects of finding gold. Another case of individuals leaving the state's sphere of influence is presented in Scott (2009), which showed how people in Southeast Asia fled the despotic regimes into the mountains of a stateless region known these days as Zomia. In both of these cases, the migration of individuals outside the state's sphere of influence was spontaneous. For the Wild West, the state did not need to provide individuals with incentives to move. For Zomia, the state did not deliberately engineer such movement for its own gain, as the region remains stateless to this day.

However, the idea that the state can purposefully incentivize the migration of individuals out of its sphere of influence to create anarchic communities has not yet been explored. Imagine that an abstract state $X$ wishes to extend its geographical power and increase its revenues. Assume that $X$ wants to achieve that by colonizing a certain amount of land and that it expects to receive a certain amount of income per unit of land that it colonizes. This income can come in the form of taxes, extraction of natural resources from the new land, the increased political prestige from bolstering its territory, and other factors that would be beneficial to the state and its bureaucrats.

However, $\mathrm{X}$ will want to colonize new lands only if the revenues from this process exceed the costs. The costs of colonization could be significant. They may consist of exploration, movement of settlers to the new land, establishment of infrastructure, and defense of the 
region. Edward P. Stringham and Caleb J. Miles $(2012,13)$ claim that "conditions favorable to state-making include an accessible, concentrated population producing easily appropriable goods that can feasibly be returned to the state centers" and that if "the cost of physically traveling to the taxable population and returning collected taxes to the state center is significantly higher than what it costs the taxable population to move out of the way, the state is cost-prohibitive." Furthermore, consider that the state can also face significant opportunity costs. For example, the armies and manpower that it diverts to colonization could be instead used to defend itself against a foreign aggressor or initiate aggression against other countries.

In this case, it is easy to imagine that if the costs of direct colonization exceed its benefits, then the state will not engage in the effort. However, this does not mean that $\mathrm{X}$ will abandon its ambition altogether. Instead, X may turn to less costly alternatives of colonizing the land. The first of such means is the use of violence. The state may modify the incentives of economic agents, driving them out of its territory and forcing them to migrate to unclaimed lands and create anarchic communities there. This could happen through, for instance, an increase of targeted violence against specific groups within the state.

As a result, individuals flee to the unoccupied regions and bear all the corresponding costs of searching for new land, settling it, and protecting it privately. Until enough land is accumulated, these communities will develop independently of the state, living under conditions of self-governance, and employing relevant mechanisms to secure and enforce peaceful cooperation, be it through private law systems, high social homogeneity, or more exotic means such as traditions or superstitions (see, for instance, Leeson 2013). Once enough land is settled, however, the state can engage in a violent conflict with the anarchic region, appropriate the colonized land, and extract revenues from it. As long as the state carefully monitors the situation and does not allow the anarchic region to grow in power disproportionately, so that the costs of confrontation become excessive, the state can obtain the land at a much lower cost.

A nonviolent approach is also possible. In this case, $\mathrm{X}$ does not utilize violence against a self-governing society to claim the land 
it covets. It may simply allow individuals to colonize the stateless frontiers and govern their communities privately for a time. Yet the state will push for an eventual assimilation of these self-governing communities. The reason for choosing an assimilation approach is that peaceful integration may have lower costs than a violent takeover. To incentivize assimilation, $\mathrm{X}$ can, for example, offer generous economic concessions upon integration. However, the decision to assimilate may take some time and the state may need to wait before it can extract incomes from the colonized territories. Then such a strategy will only work if the state does not discount its future payoffs too steeply.

We must also not forget a key Austrian insight, which is that economic systems are dynamic and prone to constant processes of disequilibrium and adjustment. As such, if the state's time preference changes or the assimilation costs become too high, the state may shift its strategy toward the violent takeover of anarchic regions. A reverse situation, where the conflict between the state and anarchic regions may become prolonged and state may opt for a softer approach, is possible as well. Now this theory will be applied to two historical examples of Russian religious sects.

\section{EMPIRICAL CASES OF STATE-PROMOTED ANARCHIC COLONIZATION}

\section{Violent Colonization Strategy: The Old Believers in Eastern Russia}

The first example of state-incentivized anarchic colonization is the case of the Russian religious sect of Old Believers. Tensions in the Russian religious life accumulated after the Russian Orthodox Church's Patriarch Nikon initiated sweeping reforms in the 1650-60s. The reform was an attempt to consolidate the authority of the church and further centralize its political power (Zenkovsky 1957, 42-51), essentially depriving regional religious communities of their autonomy. Those who did not accept the reforms and preferred to practice religion in its prereformed state were branded as heretics and mocked as "Old Believers." Thousands of Old Believers were executed, and many were imprisoned. The situation 
improved only marginally in the eighteenth century, when Peter the First replaced outright executions of Old Believers with steep taxes, which included fines for their distinct clothing and beards. Later, Russian autocrats such as Elizaveta (r. 1741-62) also subjected the Old Believers to forced labor in mining camps and factories (Beloborodov and Borovik 2017, 47-49).

Facing such repressions, many Old Believers were forced to flee the state, proclaiming it the kingdom of Satan (Zenkovsky 1957, 51). Their groups moved to the eastern and southeastern territories beyond the Ural Mountains, and outside of the Russian state's jurisdiction. These lands included the Siberian region; areas such as Altai and Tuva; and locations near the Yenisei River (Storozhenko 2015, 23-30). In the Urals, the Old Believers established numerous anarchic settlements in either hilly or dense forest terrain in the 1730 s and 1740 s.

Having been chased off the territories of the state, the Old Believers were unable to rely on formal systems of governance and had to devise their own rules privately. Due to the small size of their settlements and their religious homogeneity, the Old Believers did not need to devise extensive systems of self-governance. They mostly relied on the general meeting of villagers to resolve crucial disputes, where the "best men" would pass their verdicts (Mamsik 1989, 90-91). While petty criminals could be flogged for their misdeeds, murderers and robbers were exiled from the communities via "rafting," where the perpetrator was chained to a wooden raft, which was then set to float down a mountain river (Maltsev 2019, 10-11). ${ }^{2}$ As such, technically, the criminal could survive this punishment, but he would then have to either find a new community of Old Believers to join, or return to living under the state, which would probably mean his swift capture and imprisonment for fleeing in the first place.

Historical sources do not mention any for-profit policing firms in these anarchic communities; instead, they resorted to what Long $(2007,156-57)$ calls "defense via labor economy through an armed populace," relying on local militias armed with rifles. In the

\footnotetext{
${ }^{2}$ Of course, entering such a community meant expressing agreement with the rules ex ante, which allows us to classify these settlements as anarchic, based on their voluntary character.
} 
mountainous areas of Bukhtarma, with its narrow bridle paths, even a handful of individuals with firearms could stall a military unit.

These anarchic communities also thrived economically, mainly due to three reasons. Firstly, without the crippling oppression of the state, wealth was much easier to accumulate. Not subjected to executions or excessive taxes, the Old Believers could retain all the proceeds from their economic activities, greatly increase their capital, and continue to develop (Maltsev 2019, 10).

Secondly, the Old Believers rationally reviewed the fundamental tenets of their faith to encourage capital accumulation. Through reinterpreting the Book of Job, the Old Believers arrived at the following conclusion: as long as wealth was obtained through honest labor and trade was performed with honest weights, accumulating riches could not be considered a sin. This position contrasted greatly with the mainstream views of the Orthodox Church, which demonized the accumulation of wealth and promoted altruism and selflessness. Furthermore, similarly to the Protestant faith, Old Believers put great emphasis on honest labor, which not only was akin to a "blessing of God" to them, but also singled the Old Believers out from the mass of heretics and helped to elevate the sense of superiority of their communities (Mogilevskaja and Razumova 2012).

Thirdly, the Old Believer communities greatly depended upon mutual aid. For instance, the kamenschik (stonemason) communities near the river Bukhtarma in the Altai Mountains provided newcomers with shelter, employment, and interest-free loans to promote their starting their own enterprises.

Consequently, the incomes of some Old Believer communities increased by a factor of seventeen in just a few decades. Many of these communities, such as the kamenschiks, existed under anarchy for as long as fifty years. But a logical question arises here: Why did the Russian state allow such anarchic arrangements to exist for such an extended period? The colonization cost theory of anarchic emergence explains this outcome.

While the Old Believers built up their communities in the east, they took upon themselves all the related costs of finding and working the land. At the same time, the Russian state could not devote too many resources to colonizing the eastern frontier. The opportunity 
costs were high due to the harsh climate, the large distances to cover, and the country's involvement in numerous wars against Poland, Sweden, and the Ottoman Empire throughout the seventeenth and eighteenth centuries the country. All of these factors contributed to a high cost of direct colonization for the Russian state. Because of this high cost, the Russian state was willing to tolerate the presence of the Old Believers in the east as long as they appropriated and developed enough land.

Accordingly, Victor I. Dyatlov $(2010,7)$ writes that Old Believer migration played a decisive role in the political and economic formation of Russian territories in the east. Large sections of the Urals, Siberia, and the Far East were settled by the escapees. Nikolai N. Pokrovskiy and Natalya D. Zolnikova $(2011,170)$ make a key observation that the "old faith [became] one of the most important factors of secret colonization of Siberia." Further credibility to the intentionality of the state in its colonization efforts is provided by Sapozhnikov (1891, 62-63), who notes that the Russian army was often reluctant to apprehend the fleeing Old Believers and frequently abandoned any efforts at pursuing the adherents of the old faith.

But the state was only willing to tolerate this colonization until it became necessary to bring the anarchic communities into the fold. One of the better-researched cases of such an event concerns the Bukhtarman kamenschik communities to the southeast of the Altai Mountains. The kamenschiks established a chain of anarchic Old Believer settlements that lasted from 1740 up until 1791 (Maltsev 2019). However, the state started to threaten the villages with military advances. After a few clashes, in 1791 the Old Believers petitioned Catherine II for inclusion in the Russian state, along with the territory they had colonized. The integration of the kamenschiks occurred on quite favorable terms for the latter. They joined the state as an allogenous population, and thus, according to the laws of the Russian Empire, could continue practicing their religion without being subjected to high taxes and other discriminatory laws that were usually levied against the Old Believers. The tax that they paid, called yasak, was also very low and could be paid in animal furs and other goods instead of money. The kamenschiks also retained their autonomy and were allowed to keep their weaponry. The only duty that the state demanded of them was to protect the borders of their region (Dolzhikov 2019). 
It is evident that the Russian state incurred few costs in the process of annexing the Old Believers of Bukhtarma.

Nevertheless, the reintegration into the state did not always go smoothly for Old Believer communities. Pokrovskiy and Zolnikova $(2011,170)$ note some anarchic "isles" of colonization were met with accidental or outright targeted hostility and instead "died under the blows of state repression."

The persecution of Old Believers by the tsarist government lasted into the early twentieth century, as shown in historical records of the Tuva region, where Old Believers continued to arrive up until 1915 , settling in its most distant regions to escape state oppression.

\section{Assimilation Strategy: The Doukhobors in Canada}

The second example touches upon a radical sect called the Doukhobors (Bonch-Bruevich 1918). The sect originated in the beginning of the late eighteenth century and its name is best translated as "spirit wrestlers." Initially the name was a derogatory term, to label them as fighting against the holy spirit of God; however, the Doukhobors adopted it with a different meaning, namely that they were wrestling alongside the Holy Spirit, to uncover and preserve the voice of God in each of them (Androsoff 2011, 33). The key ideas of the Doukhobor faith were "freedom from superficial rites and from church, adherence to nonviolence, vegetarianism, abstention from alcohol and tobacco, and the rejection of governmental institutions" (Makarova 2013, 132). The Doukhobors rejected the Bible as an archaic document and instead preferred a "living" oral recitation of the main tenets of their faith.

Similarly to the Old Believers, the Doukhobors could not resort to formal governance to resolve disputes or secure peace. They also governed their communities privately, through councils of elders (Androsoff 2011, 47-48). In this way, the sect resembled a private club, which individuals join with their explicit consent to obey its established rules. If any Doukhobors were dissatisfied with the work of the elders, they could exit the sect or form a competing alternative, as evidenced by the later creation of a radical branch called the Sons of Freedom. Since the Doukhobors were pacifists, they did not arm themselves or utilize private protection firms for 
the purposes of defense, in hopes that their social homogeneity would make their peaceful existence self-enforcing. As a result, the Doukhobors formed "pockets" of anarchy in the territory of the Russian state. $^{3}$

During the more liberal reign of Alexander I, the Doukhobors enjoyed a fairly stable existence in Crimea, and their faith began to spread throughout the country. However, when Nikolai I came to power, the sect encountered heavy oppression from the state. They had their assets and landholdings confiscated and were forcibly conscripted into military service or exiled to the periphery of the Russian state unless they publicly denounced their faith and returned to Orthodox Christianity (Brokgauz and Evfron 2004, 251).

In 1895, under the growing influence of the ideas of the prolific writer Leo Tolstoy, the Doukhobors have become even more radical in their preaching of pacifism and rejection of the state. This culminated in Doukhobors holding numerous demonstrations across various Russian towns where they demonstrably burnt weapons and conscripted Doukhobors left military service. The state's wrath followed immediately-some of the Doukhobors were assaulted by state troops at these demonstrations and died, while some women were raped. Ultimately, the state subjected the Doukhobors to another exile, with full confiscation of their property. The situation was becoming dire and Leo Tolstoy had to amass funds for the Doukhobors to escape to another country. Through the efforts of a famous anarchist scholar, Peter Kropotkin, and his connections, Canada was selected as an escape destination. Soon, some eight thousand Doukhobors began their relocation to the West, and by 1899 their journey was complete (Somin 2004).

The Canadian government at that time had ambitions of becoming a more influential player on the world stage, which required more economic and territorial prestige. Furthermore, it needed to secure its northwestern territories from a potential American encroachment (Androsoff 2011, 62-63). However, the costs of colonizing these territories directly were quite high, due to the harsh climate and

\footnotetext{
${ }^{3}$ A counterargument here would be that these communities existed only by virtue of being in the "shadow" of the state. However, the Russian state did not enable their governance in any way, as attempts at resolving Doukhobor conflicts in Russian courts was frequently ignored (Androsoff 2011, 43).
} 
the lack of an agriculturally skilled populace to cultivate the land in the prairies. As such, the Canadian government decided to attract skillful immigrants to colonize the country's furthest reaches. The Doukhobors were ultimately selected due to Tolstoy and Kropotkin's lobbying and due to the fact that the sect had proven itself competent by managing to survive in harsh conditions and under constant oppression from the Russian state. We can see that the anarchic state of the international arena managed to lessen the potential for violence against the Doukhobors by the Russian state as the Canadian government "competed" for them. The problems of Doukhobors however, did not end there.

The Canadians decided to allow the Doukhobors to live under the conditions of anarchy in Saskatchewan, unsupervised by the state. Some four hundred thousand acres of land was allotted to the sect. The government was hoping that the Doukhobors would assimilate into the state in the span of one or two generations. But, the government severely miscalculated the probability of the Doukhobors assimilating. The Doukhobors wanted to continue to live in anarchy as Doukhobors, not as Canadians. Naturally, they continued to resist military conscription, registering their property, paying taxes, sending their children to public schools, and participating in state census. At the same time, their economic well-being was increasing rapidly, despite their communal economic model. Androsoff $(2011,85)$ writes that by the end of their first year in Canada, the Doukhobors worked 1,114 acres using "336 horses, 205 cows, 180 oxen, 129 ploughs, and 150 wagons." Such success could be attributed to high social homogeneity of the Doukhobors, which to a degree alleviated envy and the pressures of sharing. Furthermore, the physical strength and endurance of the group allowed them to work hard and thus receive greater marginal returns on their labor. Finally, the Doukhobors were guided by their revered leader Petr Verigin, whose management and oratory skills allowed the sect to retain its cohesion, although some radical factions such as the Sons of Freedom splintered away from the Doukhobor mainstream, discontent with Verigin's policies.

Realizing the error of their estimates, the Canadian government changed its colonization strategy from assimilation to violence, confiscating around 60 percent of the land and property cultivated by the Doukhobor sect in 1907 . The remaining property was to be 
used by the sect at the government's "pleasure" (Tugan-Baranovskiy 1919 , 26). Instead of accepting that resolution, Verigin decided to use the sect's savings to purchase land in the British Columbia province and start anew. However, some Doukhobors were no longer willing to follow their leader and preferred to obtain Canadian citizenship. Even though by 1924 the sect held about sixty-seven thousand acres of land in British Columbia and about $\$ 6$ million in property, it began to slowly fall apart. The final blow was dealt when Verigin was blown apart by a bomb planted on a train that he was riding. The loss of the efficient manager and cultic figure who had held the whole sect together disorientated the Doukhobors and led them to make a series of economic errors. Eventually the sect defaulted on a government loan, leading to their bankruptcy in 1938 and further confiscation of their property by the Canadian government (Somin 2004). This historical example shows that states can dynamically shift from one strategy of anarchic colonization to another. Ultimately for the Doukhobors, this resulted in repeated subjection to the oppression of the state.

\section{CONCLUSION}

Overall, the colonization cost theory posits that in situations where the cost of colonization is high, states allow or even encourage their subjects to establish self-governed regions. Afterwards the states will absorb these regions, reap the corresponding benefits, and avoid the costs of colonization. This analysis leads to two important conclusions. Firstly, the state may perpetuate its violence against certain social groups to keep them continuously colonizing new lands. Although other states can check this violence by harboring these oppressed communities, these states can also resort to violence in cases where the anarchic community does not want to assimilate.

Secondly, despite the fact that almost all the land in the world is now claimed by states, apart from a few regions such as Zomia (Scott 2009), states could still incentivize the emergence of anarchy in relation to at least two colonization efforts: seasteading and space colonization. There is potential for anarchic arrangements in each of these fields, as shown by Quirk and Friedman (2017) and Salter and Leeson (2014). If individuals want to keep these anarchic arrangements stable in the long run, the state to miss the critical 
moment in their development or the benefits of appropriating their colonized dwellings will have to decrease significantly. With the novelty of seasteading and space exploration, the state's capacity to seize the gains of anarchic communities in these arenas remains to be seen.

\section{REFERENCES}

Anderson, Terry L., and Peter J. Hill. 2004. The Not So Wild, Wild West: Property Rights on the Frontier. Sanford, Calif.: Stanford University Press.

Androsoff, Ashleigh. 2011. Spirit Wrestling: Identity Conflict and the Canadian "Doukhobor Problem," 1899-1999. Doctoral diss., University of Toronto.

Beloborodov, Sergei, and Yulia Borovik. 2017. Starovery Gornozavodskogo Urala: Stranicy Istorii Soglasija Beglopopovcev/Chasovennyh XVIII-nachala $X X$ v. Ekaterinburg, Russ.: Izdatelstvo Uralskogo Universiteta.

Boettke, Peter J. 2011. "Anarchism and Austrian Economics." New Perspectives on Political Economy, 7, no. 1: 125-40.

Bonch-Bruevich, Vladimir V. 1918. Duhobortsy $v$ kanadskih prerijah. Petrograd: Zhiznj i Znanije.

Brokgauz, Friedrich, and Ilya Efron. 2004. Jenciklopedicheskij slovar. Vol. 11. Moscow: Ripol Klassik.

Chartier, Gary. 2013. Anarchy and Legal Order: Law and Politics for a Stateless Society. New York: Cambridge University Press.

Dolzhikov, Vyacheslav Aleksandrovich. 2019. "Altajskaja Rus": K Istorii Narodnogo Soprotivlenija Diskriminacionnoj «Protivoraskol'nicheskoj» Politike Imperskogo Rezhima." Society and Security Insights, no. 1: 123-32.

Dyatlov, Victor I., ed. 2010. Migracii i diaspory v sociokul'turnom, politicheskom i jekonomicheskom prostranstve Sibiri Rubezhi XIX-XX i XX-XXI vekov. Irkutsk, Russ.: Irkutsk State University.

Ellickson, Robert C. 1986. "Of Coase and Cattle: Dispute Resolution among Neighbors in Shasta County." Stanford Law Review 1, no. 1: 623-87.

Friedman, David. 1979. "Private Creation and Enforcement of Law: A Historical Case." Journal of Legal Studies 8, no. 2: 399-415. 
—. 2014. The Machinery of Freedom. CreateSpace.

Hoppe, Hans-Hermann. 1998-99. "The Private Production of Defense." Journal of Libertarian Studies, 14, no. 1: 27-52.

Leeson, Peter T. 2007. "Better off Stateless: Somalia before and after Government Collapse." Journal of Comparative Economics 35, no. 4: $689-710$.

—_. 2013. “Gypsy Law.” Public Choice 155, no. 3-4: 273-92.

—. 2014. Anarchy Unbound: Why Self-Governance Works Better Than You Think. Cambridge: Cambridge University Press.

Leeson, Peter T., and Edward P. Stringham. 2005. "Is Government Inevitable? Comment on Holcombe's Analysis." Independent Review 9, no. 4: 543-49.

Long, Roderick. 2007. "Defending a Free Nation." In Anarchy and the Law: The Political Economy of Choice, edited by Edward P. Stringham, 149-62. New Brunswick, N.J.: Transaction Publishers.

Maltsev, Vladimir V. 2019. "Hearts of Stone: Analyzing Anarchic Bukhtarman Stonemason Communities in Eighteenth-Century Russia." Journal of Private Enterprise, 26, no. 4: 1-18.

Makarova, Veronika. 2013. “Doukhobor 'Freedom Seeker' Nudism: Exploring the Sociocultural Roots." Culture and Religion 14, no. 2: 131-45.

Michels, Georg B. 1999. At War with the Church: Religious Dissent in Seventeenth-Century Russia. Stanford, Calif.: Stanford University Press.

Mogilevskaja, Galina I., and Elvira M. Razumova. 2012. "Religioznyj Opyt Staroobrjadchestva i Problema Racionalnogo Hozjajstvovanija." Molodoj Uchenyj, no. 12: 583-86.

Murphy, Robert P. 2010. Chaos Theory: Two Essays on Market Anarchy. 2d ed. Auburn, Ala.: Ludwig von Mises Institute.

Pokrovskiy, Nikolai N., and Natalya D. Zolnikova. 2011. “Osvoenie Sibiri i Staroobrjadchestvo." EKO: Jekonomika i organizacija promyshlennogo proizvodstva, 440, no. 2: 168-84.

Powell, Benjamin, Ryan Ford, and Alex Nowrasteh. 2008. "Somalia after State Collapse: Chaos or Improvement?" Journal of Economic Behavior and Organization 67, no. 3-4: 657-70. 
Quirk, Joe. 2017. Seasteading: How Floating Nations Will Restore the Environment, Enrich the Poor, Cure the Sick, and Liberate Humanity from Politicians. New York: Free Press.

Rothbard, Murray N. 2006. For a New Liberty: The Libertarian Manifesto. 2d ed. Auburn, Ala.: Ludwig von Mises Institute.

Salter, Alexander W., and Peter T. Leeson. 2014. "Celestial Anarchy: A Threat to Outer Space Commerce." Cato Journal 34, no. 3: 581-96.

Sapozhnikov, Dmitriy I. 1891. Samosozhzhenie v Russkom Raskole. (So Vtoroj Poloviny XVII Veka do Konca XVIII). Istoricheskij Ocherk po Arhivnym Dokumentam. Moscow, Russ.: Moscow University Press.

Scott, James C. 2009. The Art of Not Being Governed: An Anarchist History of Upland Southeast Asia. New Haven, Conn.: Yale University Press.

Storozhenko, Alena A. 2015. "Staroobrjadcheskie migracii v Tuvu v konce XIXnachale XX v.: Marshruty, dinamika, rezultaty." In Staroobrjadcy Tuvy: Retrospektiva $i$ sovremennost, edited by Margarita Tatrintseva and Alena Storozhenko, 23-30. Saarbrücken, Ger.: Lambert Academic Publishing.

Stringham, Edward P. 2015. Private Governance: Creating Order in Economic and Social Life. New York: Oxford University Press.

Stringham, Edward P., and Caleb J. Miles. 2012. "Repelling States: Evidence from Upland Southeast Asia." Review of Austrian Economics 25, no. 1: 17-33.

Somin, N. B. 2004. “Duhobory." Chri-soc.narod.ru. Accessed Aug. 30, 2020. http://chri-soc.narod.ru/duhobor.htm.

Tannehill, Morris, and Linda Tannehill. 1993. The Market for Liberty. San Francisco: Fox and Wilkes.

Zenkovsky, Serge A. 1957. "The Russian Church Schism: Its Background and Repercussions." Russian Review, 16, no. 4: 37-58. 